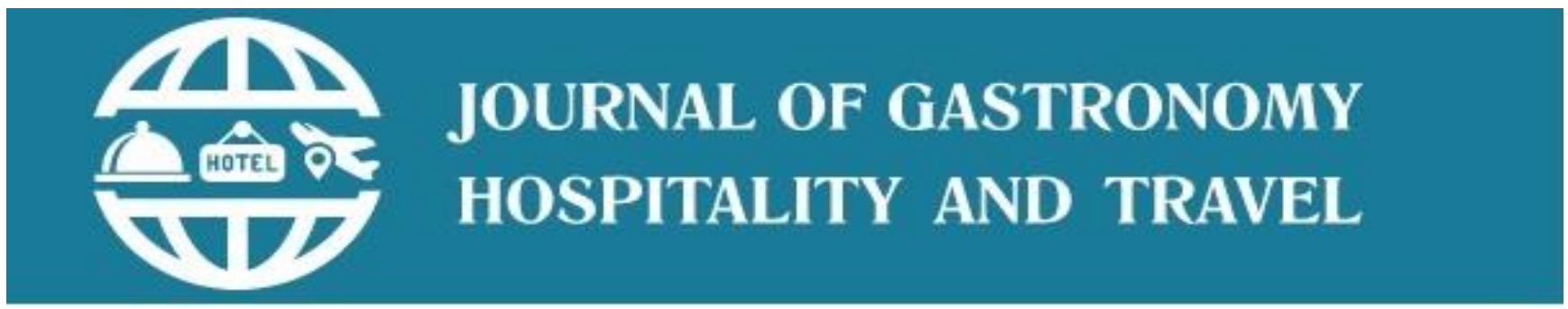

ISSN: $2619-9548$

Journal homepage: www.joghat.org, http://dergipark.gov.tr/joghat

Journal of Gastronomy, Hospitality and Travel (JOGHAT)

2020 - Volume: 3 Number: 1

Page : $3-19$

Received:26/03/2020

Revised:21/05/2020

Accepted: 24/05/2020

\title{
Research Article \\ FOOD IMAGE AND TRAVEL INTENTION: FROM NEW DELHI TO NEW YORK
}

Sandeep Chatterjee ${ }^{1}$ (orcid.org/0000-0003-0298-6494)

Paramita Suklabaidya ${ }^{2}$ (orcid.org/0000-0002-5051-2421)

${ }^{1}$ F\&B Consultant, New Jersey, USA.

${ }^{2}$ SOTHSM, Associate Professor, IGNOU, New Delhi, India.

\begin{abstract}
A tourist's destination image is formed by multiple factors. Food is one such factor that creates distinct identity for a destination; hence, food tourism is essential for destination promotion. The current study is focused on a destination's food image and its relation to traveler's likelihood to visit that destination. For this study two cities have been identified, namely, New Delhi, India and New York City, USA as cases to establish this relationship. The two mega cities are similar in being popular tourist entry points and destinations while being different in culture, heritage, and food habits. The current study uses primary tourist data in both cities to empirically examine the relation between food image and a tourist's intention to visit. The research question and related hypothesis were tested empirically to answer the research question, whether the select city's food images significantly predicts likelihood of a tourist visiting the destination. This study gives an insight into the tourist's impression of New Delhi and New York's food and dining experience; and gives impetus to destination marketing by spotlighting local cuisine and food culture.
\end{abstract}

Keywords: Food image, Food Tourism, Destination Identity, Destination Marketing

\section{Introduction}

The concept of food image in tourism has its genesis in destination image. Baud-Bovy and Lawson (1977) have defined destination image as "expressions of awareness, prejudices, impressions, imaginations and emotional thoughts toward a particular place". According to Chenini and Touaiti (2018) a tourist's perceived image is based on factors like - Motivation, perception, psychological traits, socio- economic factors, experience, media, knowledge, tourism marketing and hearsay. Food and local cuisine have become a significant component in any tourist's plan. Travellers often quote, 'tried new food' as a major trip take away (Duttagupta, 2013, p. 23, citing Tikkanen, 2007). According to Lin (2006), the unique characteristics of the food of a particular place is reflected in its destination image. The purpose of the current study is to test the interrelationship between destination's food image and behavioural intention of tourist to visit the said destination. The empirical data for the research has been gathered from two global tourist hubs - New York City in USA and New Delhi in India (Department of Homeland Security [DHS], 2018; Government of India, 2019).

To cite this document: Chatterjee, S. and Suklabaidya, P. (2020). Food Image and Travel Intention: From New Delhi to New York, 3(1), 3-19. DOI: 10.33083/joghat.2020.26

Corresponding author: chatterjee.sun@gmail.com 


\subsection{Local cuisine, image, and travel intention}

Giddens (1984) has opined that the primary motivation of travel is for people to escape "comfort of their homes." Quan \& Wang (2004) have broadened the idea by arguing that tourists like to try new cuisine as a thrill-seeking exercise to enrich the travel experience. According to Kim, Eves, and Scarles (2009), the main motivating factors for travellers to explore local cuisine are - Physical motivators, cultural motivators, inter-personal motivators, status, and prestige motivators. Novelty, in tourism is an important aspect and is related to human desire for 'thrill -seeking'. Motivation to try local cuisine is considered a major push factor for tourists drawing to a particular destination (Lee \& Crompton, 1992; Lupton, 1996). According to Ignotov and Smith, (2006) and Kim, Eves and Scarles (2009), human desire to explore new tastes, reducing tension and refreshing once mind and body are the drivers for indulging in local cuisine. The concept of 'thrill seeking' is also challenged by other studies that argue a counter narrative that many travellers exhibit 'neophobic' behaviour and stay away from unknown local cuisine (Cohen \& Avieli, 2004; D’ Antuono \& Bignami, 2012; Fischler, 1988).

The need for a "clear and consistent image" to form a strong brand is advocated by Lin, Pearson, and Cai (2011, p.31). Image, loyalty, perceived quality, and awareness are the main elements of any brand. The direct relation between image and consumer behaviour has been well documented in management studies (Almli, Verbeke, Vanhonacker, Naes \& Hersleth, 2011). A brand is usually considered to be a product, however according to Horng, Liu, Chou, and Tsai (2012) a brand may also be a tourist destination or a tourism product like cuisine. Image plays an important role in influencing decision making and other behavioural intentions. (Chen \& Tsai, 2007). The relation between image of a destination and tourist's decision to travel has been studied by various scholars in multiple locations (Baloglu \& Mangaloglu, 2001; Gallarza, Saura \& García, 2002; Nadeau, Heslop, O’Reilly, \& Luk 2008; Tapachai \& Waryszak, 2000; Wang \& Hsu, 2010). Duttagupta (2013), argues that previous studies on image and intention to travel may also be applicable for local cuisine image and travel.

According to Horng et. al. (2012), brand image of a destination and perceived quality of its local cuisine are both important in forming brand loyalty for any destination. An enhanced brand loyalty in turn results in positive travel intention.

\subsection{Food Image of New York}

New York City's diversity is best exhibited in a bouquet of cuisines that make up New York food culture and cuisine image. The ethnic restaurants of the city, diverse array of food dished out by street vendors, various food festivals and related activities, are all testimony to the rainbow image of this city. The city's culture may be a mix of its individual cultures that came from faraway lands, however it would be prudent to note that culture being a fluid and ever evolving phenomenon; New York's cuisine image has also taken shape in a way that is far more complex than the sum of its constituent parts. According to Rahman (2017), the primary cuisines that shape the city's cuisine image are Italian, Latin American and Mediterranean.

The Italian influence on New York food culture is a direct result of more than 5.5 million Italians who have migrated to the city since 1820 (Cavaioli, 2008). According to Gardaphé (2004) and Smith (2007), Italian Americans have transplanted Italian culture in New York and other parts of America, in terms of cuisine, restaurants, wine production, coffee culture and American desserts. Italian culture and cuisine are best experienced by tourists in places called 'Little Italy' seen in several parts of the city like - Manhattan, Rosebank, Belmont, Howard beach and Bensonhurst. New York's Italian American food can also be experienced at 'Eataly' - a mega food and dining store that combines European open market, American style supermarket (Whole foods), food court and learning centre (Tardi, 2007).

\subsection{Food image of Delhi}

Confining the multi-cultural capital city of a diverse country like India into a single image may be an exercise in futility. Vishal (2015), when writing about Delhi's food culture states that "there is no one Delhi." This is quite understandable for a city that has encompassed at least seven historic cities. Delhi's image of co-existing subcultures, spills over to its cuisine as well. Delhi's food image is formed by its many cultures and cuisines - Purani Dilli ka khana, quaint food joints of Hauz Khas Village, elite restaurants of Cyber Hub on Delhi Gurgaon border, Punjabi influence of West Delhi, adventurous foodies of South Delhi etc. 
A city that has garnered so much negative reputation for civility and culture may be granted some redemption for its evolved palate. Popular food critic and historian, Pushpesh Pant has compared food of Delhi to a Lachha Parantha (layered bread), where each layer adds to the diverse character of its cuisine (Pant, 2013). The city's cuisine has changed over the centuries from the times of Hindu Rajput rulers like Tomar and Chauhan $\left(9^{\text {th }}\right.$ to $12^{\text {th }}$ century) promoting Marwari, Kayasth or Baniya food of Old Delhi (Vishal, 2015; Dekaphukan, 2019). The Muslim rulers like Ghori, Mamluk and Mughals brought about the 'Karim' style rich non vegetarian cuisine to Delhi. The British rule gave Delhi a taste for 'Keventers' (Milk Shake) and 'Wenger's' (Patisserie). Post partition, influx of Punjabi refugees, gave Delhi its taste for butter chicken (Moti Mahal) and dal makhani (black Lentils) (Soofi, 2010). Post Independent industrialization brought about large number of migrants from Bengal and South India, resulting in opening of Bengali Mithai shops and Udipi restaurants. The expansion of Delhi into National Capital Region (NCR) and growth of services and IT sectors post 2000, has resulted in popularity of many new dishes like Momos, Thukpa, Litti Chokha, Vada Pao etc (Gupta \& Gordon, 2004). The last two decades also saw a major growth in international travel resulting in a global palate for Delhi. Dishes like Sushi, Shawarma, Kimchi or Tacos are no longer alien to a Delhi walla's palate (Dehlvi \& Khan, 2017).

A study (Duttagupta, 2013) on comparison of cuisine images between India and Thailand as perceived by foreign tourists indicates that Indian food is perceived as "tasty", "aromatic" and "inexpensive" by visiting tourists. The study also finds that Indian cuisine is not perceived to be "healthy/ nutritious" and is considered "difficult to digest" by foreign tourists. The prominent attributes given to Indian cuisine were - "hot" and "spicy". According to Duttagupta (2013), overall Indian cuisine had a "positive image" on foreign tourists. The study forms the basis for attributing an Image to cuisine of Delhi, which is considered to be a microcosm of Indian cuisine (The Hindu, 2016).

\section{Materials and Methods}

This study was undertaken to establish a causal relationship between tourist's food image and intention to visit.

Research question and hypotheses

Following the previous discussions and literature review the research question formulated was

'What is the relation between select destination's cuisine image and traveller's likelihood of visit?'.

The arguments and the research question led to the following hypotheses:

H1 Delhi's cuisine image has no significant effect on traveller's likelihood to visit the city.

H2 Delhi's cuisine image has a significant effect on traveller's likelihood to visit the city.

H3 New York's cuisine image has no significant effect on traveller's likelihood to visit the city.

H4 New York's cuisine image has a significant effect on traveller's likelihood to visit the city.

This study was undertaken to establish a causal relationship between tourist's food image and intention to visit. The study involved qualitative data collection, for formulation of factors or attributes, that formed food image of New York and New Delhi. These aspects of culinary tourism came from semi-structured interviews and a focus group comprising of seven experts meeting on the side-lines of a tourism seminar in New York City in January 2019. The focus group comprised of food \& beverage experts from Europe, Asia, US, and Latin-America. The inputs of the qualitative data were used to prepare a draft questionnaire, that was pre- tested among 35 random 'foodies' in New Delhi and New York, through social media channels. The final survey instrument was revised based on the pre-test inputs. The data collection method is modified version of similar techniques employed by Mills (2005); Biasutti \& Frezza (2009) and Horng et. al. (2012).

The participants for the study were selected randomly from tourists visiting Delhi and New York. The targeted areas for data collection were tourist places and prominent eateries in both cities. About half of all of all participants 
participated online via digital medium. Various Food related websites, social media groups and applications were targeted to get results from culinary tourists. Some of the digital platform targeted for data collection were, TripAdvisor, You Tube food channels, Facebook Food groups, WhatsApp Food groups, LinkedIn, and Twitter food handles. The survey was conducted between 15, January 2019 and 22, April 2019. A total of 810 questionnaires were collected from both in - person and online survey. Out of the total data collected, 789 sets of data were found error free and suitable for analysis. Hence, the response rate for the survey was 97.4 per cent. A total of 401 responses were collected from Delhi tourists and another 388 were from tourists vising New York during the survey period.

The survey instrument was modified from the earlier studies on food tourism by Shenoy (2005) and Karim (2006). The ideal sample size was based on $95 \%$ confidence level and \pm 0.05 sampling error. Since the population size is large considering New York and New Delhi, Cochran's formula was applied (Bartlett Kotrlik, \& Higgins, 2001).

$$
n_{0}=\frac{Z^{2} p q}{e^{2}}
$$

Where ' $\mathrm{e}$ ' is the margin of error or 0.05 . ' $\mathrm{p}$ ' is the estimated proportion of the population having the attribute in question. Since we are collecting data from popular food hubs of the city, we can assume that at least half the population surveyed will be having an image of local food. Hence, $p=0.5$. ' $q$ ' is $(1-p)=0.5$. ' $Z$ ' value derived from $\mathrm{Z}$ table for $95 \%$ confidence is 1.96 . Hence the sample size is:

$$
\mathrm{n}_{0}(\text { Sample size })=\frac{(1.96)^{2}(0.5)(0.5)}{(0.05)^{2}}=384.16
$$

Reliability test was performed on all variables in multi-variable questions of the questionnaire. The test was conducted to check consistency of all dimensions of the scale. Reliability statistics showed Cronbach's Alpha of .899 and .890 for 18 attributes of New Delhi and New York. According to Hair (2001), Cronbach's alpha coefficient of .7 and above are deemed reliable.

The research question and related hypothesis was tested in three distinct phases. In the first phase an exploratory study was conducted with descriptive statistics to find out the salient factors comprising the cuisine image of the two destinations. The second phase was an exploratory factor analysis that was conducted to extract underlying factors of cuisine images in both cities, which were later compared for finding statistically significant variables. In the final phase of the study, multiple linier regression model was applied on all underlying factors in the select cities.

\section{Results}

\subsection{Respondent's Demographics}

A total of 810 questionnaires were collected from both in - person and online survey. Out of the total data collected, 789 sets of data were found error free and suitable for analysis. Hence, the response rate for the survey was 97.4 per cent. 401 responses were collected from tourists visiting Delhi and 388 were from tourists vising New York City.

Table 1. Response rate by demographics.

\begin{tabular}{|l|l|l|}
\hline Demographic characteristics & Delhi tourist's response (\%) & New York tourist's response (\%) \\
\hline Gender & & \\
\hline
\end{tabular}




\begin{tabular}{|l|l|l|}
\hline Male & 42.2 & 40.2 \\
\hline Female & 57.8 & 59.8 \\
\hline $\begin{array}{l}\text { Age } \\
\text { less than 20 }\end{array}$ & 4.7 & 5.0 \\
\hline 30 to 39 & 59.1 & 62.9 \\
\hline $\begin{array}{l}40 \text { to } 49 \\
\text { 50 to 59 }\end{array}$ & 16.2 & 13.9 \\
\hline 60 and above & 18.1 & 15.0 \\
\hline Nationality & 0.8 & 1.4 \\
\hline India & 1.1 & 1.9 \\
\hline USA & 31.3 & 17.1 \\
\hline others & 10.9 & 14.5 \\
\hline Education & 57.8 & 68.4 \\
\hline Non- graduate & 19.5 & 21.1 \\
\hline Graduate & 45.3 & 45.0 \\
\hline Post-graduate & 35.2 & 33.9 \\
\hline Note. N 789 & & \\
\hline
\end{tabular}

Note. $\mathrm{N}=789$

Demographic profile of the respondents is shown in table 1. Gender of the respondents were fairly equal with 42.2 and 40.2 male and 57.8 and 59.8 female respondents. Most respondents were between the ages of 20 and 29 years $(59.1 \%$ and $62.9 \%)$. Both surveys had a varied mix of nationalities participating at random. Delhi survey had 31.3 $\%$ responses from Indian nationals, $10.9 \%$ from US nationals and a majority of respondents were from various other nationalities (57.8\%). The New York survey was also filled by various nationalities. $14.5 \%$ local American tourists participated in the survey, alongside $17.1 \%$ Indians and $68.4 \%$ other nationalities. Most respondents to the survey were graduates $(45.3 \%$ and $45.0 \%)$ while many others were post-graduates $(35.2 \%$ and $33.9 \%)$.

\subsection{Descriptive statistics - Destination cuisine image}

The select cities - Delhi and New York were compared in terms of cuisine image attributes. The comparison of mean scores indicate that in 11 out of 18 attributes Delhi scores higher than New York. In other words. Delhi has $61.11 \%$ of higher mean scores as compared to New York, which has $38.88 \%$ higher mean scores. This may be indicative of the fact that this study finds Delhi to have a stronger cuisine image than New York.

Table 2. Comparing cuisine images of Delhi and New York

\begin{tabular}{|l|l|l|}
\hline Cuisine image dimensions & DELHI & NEW YORK \\
\hline The most popular cuisine in the country & 5.02 & $\mathbf{5 . 1 2}$ \\
\hline Historic food options & $\mathbf{5 . 0 6}$ & 4.57 \\
\hline Variety of food options & 5.68 & $\mathbf{5 . 7 2}$ \\
\hline
\end{tabular}




\begin{tabular}{|l|l|l|}
\hline Good quality of food & 5.74 & $\mathbf{5 . 9 8}$ \\
\hline Package food walks and tours & $\mathbf{4 . 1 9}$ & 4.11 \\
\hline Reasonable price for dining-out & $\mathbf{5 . 6 4}$ & 5.09 \\
\hline Many attractive restaurants & 5.47 & $\mathbf{5 . 6 5}$ \\
\hline Unique cultural experience & $\mathbf{5 . 8 8}$ & 5.2 \\
\hline Easy access to restaurants & 5.54 & $\mathbf{5 . 5 6}$ \\
\hline Variety of specialty restaurants & 5.37 & $\mathbf{5 . 5 6}$ \\
\hline Regionally produced food products & $\mathbf{5 . 3 0}$ & 4.66 \\
\hline Offers best street food in the country & $\mathbf{5 . 2 9}$ & 4.87 \\
\hline Unique street food vendors & $\mathbf{5 . 2 3}$ & 4.91 \\
\hline Much literature on food and tourism & $\mathbf{4 . 3 8}$ & 4.04 \\
\hline Exotic cooking methods & $\mathbf{4 . 8 5}$ & 4.2 \\
\hline Delicious food & $\mathbf{6 . 0 7}$ & 5.83 \\
\hline Vegetarian food options & $\mathbf{4 . 5 3}$ & 4.15 \\
\hline Hygienic food options & 5.45 & $\mathbf{5 . 8}$ \\
\hline
\end{tabular}

$\mathrm{N}=789 ;$ Scale: 1 = Strongly Disagree; 7 = Strongly Agree

The comparison of descriptive statistics of Delhi and New York (table 2) indicates that both cities have their unique food image. The higher mean scores for certain attributes are indicative that overall Delhi's cuisine has an image of being 'delicious' and provides a 'unique cultural experience'. New York's cuisine has an image of 'quality' and 'hygiene'. The food image of Delhi is, in part reflective of the food image of India.

\subsubsection{Likelihood of visit}

The respondents in both the cities were asked how likely they are to visit Delhi or New York for its food and dining experience.

Table 3. The likelihood of visit to Delhi/ New York for Culinary Tourism

\begin{tabular}{|l|l|l|l|}
\hline & $\mathrm{N}$ & Mean & Std. Deviation \\
\hline $\begin{array}{l}\text { How likely are you to visit NEW YORK for its food } \\
\text { and dining experience? }\end{array}$ & 388 & 3.59 & 1.196 \\
\hline $\begin{array}{l}\text { How likely are you to visit DELHI for its food and } \\
\text { dining experience? }\end{array}$ & 400 & 3.38 & 1.271 \\
\hline
\end{tabular}

Scale: 1 = Most Unlikely; 5 = Most Likely

Table 3 represents the descriptive statistics for the question on 'likelihood of visit to Delhi/ New York for food and dining experience' $(\mathrm{m}>3)$. As evident from the results, both cities seem to have a strong likelihood for tourists visit specifically for culinary tourism. New York however had a higher mean score $(\mathrm{m}=3.59)$, indicating that it more tourists would prefer going to New York than Delhi for culinary tourism. Overall, the 'cuisine image' and 'likelihood to visit' studies indicates that although Delhi has a stronger 'cuisine image' it lacks in attracting tourists when compared to New York for culinary tourism. 


\subsection{Factor Analysis}

Delhi

An exploratory factor analysis was carried out on all of Delhi's 18 cuisine image variables. Principal axis factoring (PAF) with oblique rotation was applied as the factors were found to be fairly correlated. The scree plot and Pattern matrix table provided an interpretable simple structure, indicating three distinct factor extractions. Three new and underlying factors were extracted using the analysis. The three factors explained $55.195 \%$ of total variance. The three extracted factors were then given labels (names) based on the common theme shared by the said variables constituting the factor.

Bartlett's test of sphericity was conducted and found significant. The Kaiser-Meyer-Olkin measure of sampling adequacy of .899 exceeds the required value (> .6). Hence, factorability of the matrix is assumed (Snedecor \& Cochran, 1989).

Table 4. Factors for Delhi's Cuisine Image

\begin{tabular}{|c|c|c|c|}
\hline Factors & Loadings & Eigenvalue & $\%$ of variance explained \\
\hline \multicolumn{4}{|l|}{ Delhi’s Cuisine image } \\
\hline $\begin{array}{l}\text { Delhi offers Variety of } \\
\text { food options }\end{array}$ & .766 & \multirow{12}{*}{7.301} & \multirow{12}{*}{40.560} \\
\hline $\begin{array}{l}\text { Delhi offers Good } \\
\text { quality food }\end{array}$ & .759 & & \\
\hline $\begin{array}{l}\text { Delhi offers Many } \\
\text { attractive restaurants }\end{array}$ & .695 & & \\
\hline $\begin{array}{l}\text { Delhi offers the Most } \\
\text { popular cuisine in the } \\
\text { country }\end{array}$ & .686 & & \\
\hline $\begin{array}{l}\text { Delhi offers Delicious } \\
\text { food }\end{array}$ & .683 & & \\
\hline $\begin{array}{l}\text { Delhi offers } \\
\text { Reasonable price for } \\
\text { dining-out }\end{array}$ & .677 & & \\
\hline $\begin{array}{l}\text { Delhi offers Easy } \\
\text { access to restaurants }\end{array}$ & .572 & & \\
\hline $\begin{array}{l}\text { Delhi offers Unique } \\
\text { cultural experience }\end{array}$ & .545 & & \\
\hline $\begin{array}{l}\text { Delhi offers Variety of } \\
\text { specialty restaurants }\end{array}$ & .534 & & \\
\hline $\begin{array}{l}\text { Delhi offers Historic } \\
\text { food options }\end{array}$ & .527 & & \\
\hline $\begin{array}{l}\text { Delhi offers Regionally } \\
\text { produced food products }\end{array}$ & .424 & & \\
\hline $\begin{array}{l}\text { Delhi offers Hygienic } \\
\text { food options }\end{array}$ & .422 & & \\
\hline
\end{tabular}




\begin{tabular}{|l|l|l|l|}
\hline Delhi's Food-Cultural image & & \\
\hline $\begin{array}{l}\text { Delhi offers Much } \\
\text { literature on food and } \\
\text { tourism }\end{array}$ & .711 & 1.575 & 8.751 \\
\hline $\begin{array}{l}\text { Delhi offers Exotic } \\
\text { cooking methods }\end{array}$ & .592 & & \\
\hline $\begin{array}{l}\text { Delhi offers Vegetarian } \\
\text { food options }\end{array}$ & .486 & & \\
\hline $\begin{array}{l}\text { Delhi's Street food image } \\
\text { Delhi offers Best street } \\
\text { food in the country }\end{array}$ &.- .871 & & 5.884 \\
\hline $\begin{array}{l}\text { Unique street food } \\
\text { vendors }\end{array}$ & -.863 & & \\
\hline $\begin{array}{l}\text { Total variance } \\
\text { explained }\end{array}$ & & & 55.195 \\
\hline
\end{tabular}

Exploratory factor analysis of Delhi's cuisine image, given in table 4 indicates three underlying factors that explained $55.195 \%$ of total variance. The first factor (F1) was labeled 'Delhi's cuisine image' and it was composed of 12 variables. This first factor had an Eigen value of 7.301 and it explained $40.560 \%$ of total variance. The second factor (F2) was labeled 'Delhi's food-culture image' and it comprised of 3 variables. The second factor had an Eigen value of 1.575 and it explained $8.751 \%$ of variance. The third factor (F3) was labeled 'Delhi's Street food image' and it comprised of 2 variables. This factor had an Eigen value of 1.059 and it explained $5.884 \%$ of variance.

\section{New York}

A factor analysis of New York's 18 cuisine images was done using principal axis factoring (PAF) with oblique rotation. This extraction method was applied as the factors were found to be fairly correlated. The scree plot and Pattern matrix table provided an interpretable simple structure, indicating four distinct factor extractions that explained $59.826 \%$ of variance. Each of these 4 factors were named based on the shared characteristics of the constituent variables.

Table 5. Factors for New York’s Cuisine Image

\begin{tabular}{|l|l|l|l|}
\hline Factors & Loadings & Eigenvalue & $\%$ of variance explained \\
\hline $\begin{array}{l}\text { New York's Food-Cultural Image } \\
\text { Much literature on food } \\
\text { and tourism }\end{array}$ & .801 & & \\
\hline $\begin{array}{l}\text { Exotic cooking } \\
\text { methods }\end{array}$ & .729 & 6.574 & 36.524 \\
\hline $\begin{array}{l}\text { Historic food options } \\
\text { Package food walks } \\
\text { and tours }\end{array}$ & .643 & & \\
\hline New York's Cuisine image & & \\
\hline
\end{tabular}




\begin{tabular}{|c|c|c|c|}
\hline $\begin{array}{l}\text { Variety of specialty } \\
\text { restaurants }\end{array}$ & .731 & \multirow{6}{*}{1.924} & \multirow{6}{*}{10.688} \\
\hline $\begin{array}{l}\text { Easy access to } \\
\text { restaurants }\end{array}$ & .728 & & \\
\hline Good quality of food & .613 & & \\
\hline $\begin{array}{l}\text { Many attractive } \\
\text { restaurants }\end{array}$ & .599 & & \\
\hline Variety of food options & .587 & & \\
\hline Delicious food & .429 & & \\
\hline \multicolumn{4}{|l|}{$\begin{array}{l}\text { New York's Street } \\
\text { Food image }\end{array}$} \\
\hline $\begin{array}{l}\text { Offers best street food } \\
\text { in the country }\end{array}$ & -.922 & \multirow{3}{*}{1.251} & \multirow{3}{*}{6.949} \\
\hline $\begin{array}{l}\text { Unique street food } \\
\text { vendors }\end{array}$ & -.671 & & \\
\hline $\begin{array}{l}\text { Reasonable price for } \\
\text { dining-out }\end{array}$ & -.408 & & \\
\hline \multicolumn{4}{|c|}{ New York's cuisine popularity image } \\
\hline $\begin{array}{l}\text { The most popular } \\
\text { cuisine in the country }\end{array}$ & -.466 & 1.020 & 5.665 \\
\hline $\begin{array}{l}\text { Total variance } \\
\text { explained }\end{array}$ & & & 59.826 \\
\hline
\end{tabular}

Exploratory factor analysis of New York cuisine image, as given in table 5 indicates four underlying factors that explained $59.826 \%$ of total variance. The first factor (F1) was labeled 'New York's Food-Cultural Image' and it had four variables. The total variance explained by Factor one was $36.524 \%$ with an Eigen value of 6.574. The second factor (F2) was named 'New York's Cuisine image' which consisted of six variables. The second factor had an Eigen value of 1.924 and it explained 10.688 \% of variance. The next factor (F3) was labeled 'New York's Street Food image' and it consisted of three items. This factor had an Eigen value of 1.251 and it explained 6.949 $\%$ of variance. The fourth factor (F4) was named 'New York's cuisine popularity image' and it had only one variable. This factor had an Eigen value of 1.020 and it explained $5.665 \%$ of variance.

\subsubsection{Overall factor comparison}

To compare the factor analysis of both cities, all variables were factored under various extractions. The comparison points that both destinations - Delhi and New York have different sets of variables that constitute the extracted factors. Only 3 variables out of 18 have same factors in both cities - Historic food options; Offers best street food in the country; Unique street food vendors. Most variables that are repeated in both cities like 'Delicious food' and 'Most popular cuisine' etc. have a different factor head. A few factors were exclusively unique to the city like, 'Regionally produced food products' and 'Vegetarian food options' for Delhi and 'Package food walks and tours' for New York.

In general, the comparison indicates that both cities may have similar cuisine images factors, but the tourists have a distinct image of both cities. Factors that form a strong image in one city may not be the same in another. For 
example, an item like 'Unique cultural experience' is F1 for Delhi but only F3 in New York, indicating that tourists associate 'Unique cultural experience' more strongly with Delhi than with New York.

\subsection{Regression Analysis}

Delhi

The initial multiple linier regression model using all three underlying factors for Delhi depicted an $\mathrm{R}$ square value of .122, this means that the model predicts $12.2 \%$ of all variance in dependent variable is explained by independent variables. The F- ratio of 17.651 was found significant $(p<0.001)$ and this suggests that the equation model is reliable. Study of the coefficients table indicates that t-values for two factors (F1 and F2) were significant, however Factor 3 was found not significant. A step wise regression was then followed to form Model B with the exclusion of Factor 3 from the equation.

Following the results of initial Model, stepwise regression analysis was conducted. The stepwise regression models indicate that both 'Delhi Food-culture image' (F2) and 'Delhi cuisine image' (F1) variables have been entered into the regression equation. Model 1 only includes Delhi Food-culture image (F2) as a predictor (constant) whereas Model 2 includes both F2 and F1 as predictors. Model 1 explains 9.1 per cent of the variability in 'Likelihood of visit to Delhi', $\mathrm{F}(1,384)=38.455, \mathrm{p}<.05$ and Model 2 explains 12.2 per cent of variability in 'Likelihood of visit to Delhi', $\mathrm{F}(2,383)=26.545, \mathrm{p}<.05$. The third independent variable, 'Delhi street food image' (F3), failed to meet the selection criteria, as indicated by non-significant $t-$ value $(p>.05)$ and hence excluded from the models.

Table 6. Final Stepwise regression models

\begin{tabular}{|c|c|c|c|c|c|c|}
\hline \multicolumn{6}{|c|}{ Coefficients $^{\mathrm{a}}$} & \\
\hline \multirow{2}{*}{\multicolumn{2}{|c|}{ Model }} & \multicolumn{2}{|c|}{$\begin{array}{l}\text { Unstandardized } \\
\text { Coefficients }\end{array}$} & \multirow{2}{*}{$\begin{array}{l}\text { Standardized } \\
\text { Coefficients } \\
\text { Beta }\end{array}$} & \multirow[t]{2}{*}{$\mathrm{t}$} & \multirow[t]{2}{*}{ Sig. } \\
\hline & & B & Std. Error & & & \\
\hline \multirow[t]{2}{*}{1} & (Constant) & 2.072 & .217 & & 9.562 & .000 \\
\hline & F2 Delhi Food-Culture Image & .281 & .045 & .302 & 6.201 & .000 \\
\hline \multirow[t]{3}{*}{2} & (Constant) & .915 & .382 & & 2.397 & .017 \\
\hline & F2 Delhi Food-Culture Image & .198 & .050 & .212 & 3.947 & .000 \\
\hline & F1 Delhi Cuisine Image & .279 & .076 & .197 & 3.660 & .000 \\
\hline
\end{tabular}

a. Dependent Variable: Likelihood of visit DEL

Statistics for the equation

The model summary from step wise regression analysis suggests that Model 2 with $\mathrm{R}$ square .122 explains the variability in our dependent variable (Likelihood of visit) better than Model1 with R square .091 .

Hence, the final regression model is as given below:

$\mathrm{Y}=.915+.198 \mathrm{XF} 2+.279 \mathrm{XF} 1$ where,

$\mathrm{Y}=$ Likelihood of visit

F2 = (Delhi offers Much literature on food and tourism; Delhi offers Exotic cooking methods; and Delhi offers Vegetarian food options)

F1 = (Delhi offers Variety of food options; Delhi offers Good quality of food; Delhi offers Many attractive restaurants; Delhi offers the Most popular cuisine in the country; Delhi offers Delicious food; Delhi offers Reasonable price for dining-out; Delhi offers Easy access to restaurants; Delhi offers Unique cultural experience; 
Delhi offers Variety of specialty restaurants; Delhi offers Historic food options; Delhi offers Regionally produced food products; and Delhi offers Hygienic food options)

As a result of Delhi's initial regression analysis, we find all three independent variables (Delhi's Cuisine image, food culture image and street food image) together explain 12.2 percent variance of (R square) in Tourist's likelihood of visit to Delhi. An examination of the $t$ - values in table 6 indicates that Delhi's cuisine image (F1) as well as Delhi's Food-culture image (F2) contribute to the prediction of Tourist visiting Delhi for food and dining experience. The model also indicates that Delhi's street food image (F3) has no significant impact on Likelihood of tourist visiting Delhi for food and dining. Therefore, in answer to research question, the analysis indicates that Delhi's cuisine (F1 - Delhi's cuisine image and F2 - Delhi's food-culture image) significantly predicts 'Likelihood of tourist visiting Delhi for food and dining' $-\mathrm{F}(3,382)=17.651$, p <.05. However, F3 - 'Delhi's street food image' is not a significant predictor.

The findings of Model 2 can be explained by using standardized coefficients (Beta) as, for every 1 unit increase in the independent variable of Factor 2 may result in .212 increase in dependent variable (Likelihood of visit) when keeping other variables constant. Also, every 1 unit increase of Factor 1 is predicted to increase 'likelihood of visit' by .197 units. However, if we use standardized coefficients (Beta) to interpret the result, we also find that Model 1, i.e. when we only consider F2 - 'Delhi food-culture' as our only predictor (Beta $=.302)$, has the strongest influence on our dependent variable (likelihood of visit).

The findings of the analysis support the research question and Hypothesis number two.

'H2 Delhi's cuisine image has a significant effect on traveller's likelihood to visit the city.'

\section{Hence, H1 'Delhi's cuisine image has no significant effect on traveller's likelihood to visit the city.' Is rejected and $\mathrm{H} 2$ is accepted.}

\section{New York}

The initial Regression model depicted an R square of .170 which implying that 17 percent of total variance in dependent variable (Likelihood of visit) may be explained by independent variables (F1, F2, F3 and F4). The F ratio of 19.041 was significant at $p<0.001$ and suggested that the results shown by the regression model is reliable. The t- values of Factor 1 (New York food-culture image) and Factor 3 (New York street food image) were found unreliable $(\mathrm{p}>0.05)$. These two variables were excluded from the next regression analysis. The second regression was performed with variables F2 (New York cuisine image) and F4 (New York cuisine popularity image).

Table 2. Final Regression model with two constant variables - F2 and F4.

\begin{tabular}{|c|c|c|c|c|c|c|}
\hline \multicolumn{6}{|c|}{ Coefficients $^{\mathrm{a}}$} & \\
\hline \multirow{2}{*}{\multicolumn{2}{|c|}{ Model }} & \multicolumn{2}{|c|}{$\begin{array}{l}\text { Unstandardized } \\
\text { Coefficients }\end{array}$} & $\begin{array}{l}\text { Standardized } \\
\text { Coefficients }\end{array}$ & \multirow[t]{2}{*}{$\mathrm{t}$} & \multirow[t]{2}{*}{ Sig. } \\
\hline & & B & $\begin{array}{l}\text { Std. } \\
\text { Error }\end{array}$ & Beta & & \\
\hline \multirow[t]{3}{*}{1} & (Constant) & .673 & .374 & & 1.801 & .073 \\
\hline & F2 New York Cuisine image & .338 & .071 & .248 & 4.730 & .000 \\
\hline & $\begin{array}{l}\text { F4 New York Cuisine popularity } \\
\text { image }\end{array}$ & .194 & .043 & .237 & 4.537 & .000 \\
\hline
\end{tabular}

a. Dependent Variable: Likelihood of visit NYC 
The study of the variables table indicates both Factor 2 (F2) and Factor 4(F4) are significant predictors in the regression equation. F2 and F4 variables together explain 16.9 percent of variability in 'likelihood of visit', F $(2,375)=38.161, \mathrm{p}<0.001$. Variables $\mathrm{F} 1$ and F3 were omitted in the final regression as they exhibited nonsignificant $\mathrm{t}$ - values $(\mathrm{p}>0.05)$ in initial regression Model.

Statistics for the equation

The model summary from two regression models indicate no significant change in R square (.017) was noticed after second regression. The F-ratio in second regression model (Model 2), increased to 38.161 and was significant at $\mathrm{p}<0.001$.

Hence, the final regression model for New York is show as follows:

$\mathrm{Y}=.673+.338 \mathrm{XF} 2+.194 \mathrm{XF} 4$ where,

$\mathrm{Y}=$ Likelihood of visit.

F2 = (New York offers Variety of specialty restaurants; New York offers easy access to restaurants; New York offers good quality of food; New York offers many attractive restaurants; New York offers variety of food options; New York offers delicious food)

F4 = (New York offers the most popular cuisine in the country)

Final Regression Model for New York shows that when considering unstandardized coefficients, for every 1-unit increase in independent variable, Factor 2, results in .338 unit increase in dependent variable (Likelihood of visit) and every 1- unit increase in independent variable, Factor 4, results in only .194 increase in dependent variable, when other variables are constant. However, when we use Beta (standardized coefficient) to interpret the results we see that Factor $2($ Beta $=.248)$ has slightly more influence than Factor $4($ Beta $=.237)$ on 'Likelihood of visit'.

The results for initial regression analysis on New York suggest that all four independent variables together explain 17 per cent of variance ( $\mathrm{R}$ square) in 'Likelihood of visit', which may be considered significant as indicated by Fvalue of 19.041. An examination of the t- values indicates that Factor 2 (New York cuisine image) and Factor 4 (New York cuisine -popularity image) both contribute to the prediction of 'likelihood of travel'. Therefore, in answer to research question, it may be said that Factor 2 (New York cuisine image) and Factor 4 (New York cuisine-popularity image) significantly predicts 'likelihood of travel' $-\mathrm{F}(4,373)=19.041, \mathrm{p}<.05$. However, F1 (New York food-culture image) and F3 (New York street food image) are not significant predictors.

The findings of the analysis support the research question and Hypothesis number four.

'H4 New York's cuisine image has a significant effect on traveller's likelihood to visit the city'.

\section{Hence, 'H3 New York's cuisine image has no significant effect on traveller's likelihood to visit the city' is rejected and $\mathrm{H} 4$ is accepted.}

The results found in the study are consistent with earlier study by Karim and Chi (2010) on "Relationship Between Food Image and Travelers' Visit Intention" in France, Italy, and Thailand.

\subsubsection{Overall comparison across destinations}

After comparing regression models of Delhi and New York, it may be summarized that in general, Delhi displayed an R square of .122 and New York had an R square of .170. Hence, Delhi's independent variables (Factors) together could explain $12.2 \%$ variance in 'Likelihood of visit', whereas New York's independent variables (Factors) could explain a slightly better, $17 \%$ of the variance (Likelihood of visit).

The R square \% of 12.2 and 17 are slightly better than earlier studies done by Karim (2006) on food image of France, Italy and Thailand. The current study also validates previous finding of the study - "image of Thai food has a positive relationship with intention to revisit Thailand" (Lertputtarak, 2012). 
It may also be concluded that F2 - Delhi food-culture image $($ Beta $=.212)$ and F1 - Delhi cuisine image $($ Beta $=$ .196) were found to be significant predictors for 'Likelihood of visit' in case of Delhi. In comparison, F2 - New York cuisine image $($ Beta $=.241)$ and F4 - New York cuisine-popularity image $($ Beta $=.237)$, were the salient predictors of 'Likelihood of visit' for the city of New York.

The analysis also concludes that certain independent variable (factors) in both cities were found insignificant and had to be removed from the regression model. F3 - Delhi street food image, F1 - New York food-culture image and F3 - New York street food image were all found statistically insignificant predictors $(\mathrm{p}>0.05)$ for both cities.

According to Baloglu and McClearly (1999), destination image affects a tourist's maiden visit to the destination and Bigné, Sánchez, and Sánchez (2001), has found similar results while studying revisit based on destination image. According to Lertputtarak (2012), food is a psychological need for a tourist and image of Thai food is found to have a positive relation to intention of visit. In yet another similar study Horng et. al. (2012), find that brand image of Taiwan has a positive effect on travel intention for culinary tourism.

\section{Conclusion}

Food or culinary tourism has become one of the major trends for destination marketing. Local food and cuisine are finally being recognized as a cultural marker or identity marker by tourists. A destination's cuisine or food culture is now as important as traditional identity markers like language, dress, personal style, art, music, or cinema. Every country and tourist destination are competing for a unique selling proposition to position itself competitively in the market. Culinary and wine tourism has proved itself to be a fillip in increasing tourism for various destinations like Hong Kong, Singapore, Turkey, Spain, Italy, France, and California, to name a few. The current study was focused on relation between select destination's cuisine image and traveler's likelihood of visit. The destinations selected were - New York and New Delhi - two cities well known for their diverse culture and cuisine. The study also selected these particular destinations as most studies on culinary tourism have focused on South Asia, Central Asia and Europe. No studies were found that compared food tourism in North America with South East Asia.

The first part of the study was focused on finding out the salient factors comprising the cuisine image of the two destinations. The descriptive statistics applied on the data gathered from both destinations indicate that both New Delhi and New York have their own unique food image in the minds of the tourist. For example, 'Delhi offers delicious food' and 'Delhi offers unique cultural experience' were the two most common attributes for the city. New York' image on the other hand was focused on 'New York offers good quality of food' and 'New York offers hygienic food options'. The results are consistent with the broader destination image of the two cities. Delhi is known for its history, culture and variety of Indian cuisine and New York reflects America's perception of quality and cleanliness. However, some parts of New York may be filthier than that of New Delhi. The study also asked tourists in both cities about their likelihood of visit to Delhi or New York for food and dining experience. The results showed that most tourists were likely to visit the cities for culinary tourism. New York scored marginally higher than Delhi in terms of popularity.

In the next phase of the study, an exploratory factor analysis was conducted to extract underlying factors of cuisine images in both cities, which were later compared for finding statistically significant variables. The resultant underlying factors accountant for more than 55\% and 59\% of total variance in Delhi and New York. The findings helped in characterizing the primary factors that shape the cuisine image of these cities. The most prominent factor for Delhi (F1), named 'Delhi's Cuisine Image' had characteristics like - Delhi offers Variety of food options; Delhi offers Good quality of food; Delhi offers Many attractive restaurants etc. In case of New York, the most prominent factor (F1) was labeled 'New York's Food-Cultural Image' and it had four variables - Much literature on food and tourism; Exotic cooking methods; Historic food options and Package food walks and tours. When comparing factors of both cities it was noted that both cities had a few similar cuisine image factors, like - Historic food options; Offers best street food in the country; Unique street food vendors. It was also found that certain images were more prominent to one city than another. For example, tourists to Delhi consider it to have 'the most 
popular' cuisine in the country (F1), while tourists in New York do not consider in to be a popular American cuisine (F4). Similarly, Delhi is considered to have 'Reasonable price for dining-out' and 'Unique cultural experience' (F1) and less so for New York (F3). When comparing the two food images, certain unique factors also emerged, like 'Package food walks and tours' (F1) were found prominent to New York City and 'Regionally produced food products' (F1) was unique to New Delhi. The results of the factor analysis are also aligned with the general notion that Delhi's cuisine is well defined in the mind of a tourist, whereas New York's vibrant dining culture is more prominent. Previous studies by Hunt (1975); Scott, Schewe, and Frederick (1978) and Karim (2006) have indicated that knowledge of local cuisine is important factor in forming food image. In case of Delhi, most tourists are Indians who have a fair knowledge of the cuisine and also the foreign tourists visiting Delhi, try to find out about Indian food culture. In case of New York, most tourists are Europeans, who have either a dim view or limited understanding of American cuisine.

In the final phase of the study, multiple linier regression model was applied on all underlying factors (Food images) in the select cities with 'likelihood of visit' being the dependent variable. The regression analysis was run several times to ascertain the factors that most significantly contribute a causal effect in tourist behavior. The study confirms that there is a positive relation between destination's food image and tourist's likelihood to visit. When comparing the $\mathrm{R}$ square value of both cities, it is indicative that New York's food image has a stronger relation to travel intention than Delhi.

The result of regression analysis is in-line with real world experience, literature review and focus group interview have all indicated that destination marketing agencies of New York like 'NYC \& Company' and 'Brand USA' are constantly working towards building a stronger destination and culinary image for New York City. Destination marketing agencies in India like Incredible India and Delhi Tourism have also realized the potential of culinary tourism as is evident from the prominence given to food on their websites. However, critical difference remains, as in emerging markets like India, culinary tourism is still considered an object to glorify and study, rather than an experience to enjoy and savor.

The current study is a pioneering work and an exploratory study of linkage between food image and travel when comparing two diverse destinations - Delhi and New York. Hence, the academic implication of the study is that it bridges this gap in literature and provides a foundation for similar empirical research on food tourism in North America and South Asia. The direct managerial implication of the research is that data gathered on tourist's perception about the two cuisines can help destination promotors of both destinations to formulate cuisine-based marketing strategies that may appeal to potential tourists. For example, most foreign tourists in India want to try Indian food but are discouraged by poor hygienic conditions of street carts and public eateries. The popular global perception that Indian food is 'difficult to cook' and 'too spicy to taste' can be addressed by incorporating cooking classes in tourist itinerary. The study also finds that despite recent emergence of many 'food walks' in Delhi, general tourist, by and large are still unaware of these or are reluctant to participate. Ministry of tourism can change this by providing relevant information via websites and mobile apps. A concept called 'Restaurant Week' that incidentally started from New York can be tried in Delhi, where participating restaurants in the city give deep discounts for one week to encourage tourists to try their cuisine.

In case of New York, one would imagine that little promotion via food or otherwise would be required. However, the current study throws some incredible light on the perception of global tourists visiting the city. The study finds that New York's food image is more reflective of its vibrant dining culture than a reflection of its cuisine. Most tourists had little knowledge of American cuisine apart from few popular items like Pizza and Hotdog. The destination promotors of the city like 'NYC and company' and 'I love NY' can improve this image by showcasing great local cuisines like New American cuisine, Deli food, Southern Cuisine, Traditional New York food etc., instead of generic 'McDonaldization' of food.

To conclude, food is an important part of travel. A destination's image is linked to its food image and if destination's food image is projected correctly, it can be a powerful tool for promoting any destination. 


\section{References}

Almli, V.L., Verbeke, W., Vanhonacker, F., Naes, T., \& Hersleth, M. (2011). General image and attribute perceptions of traditional food in six European countries. Food Quality and Preference, 22, 129-138.

Baloglu, S., \& Mangaloglu, M. (2001). Tourism destination images of Turkey, Egypt, Greece, and Italy as perceived by U.S.-based tour operators and travel agents. Tourism Management, 22(1), 1-9.

Baloglu, S., \& McCleary, K.W. (1999). A model of destination image formation. Annuals of Tourism Research, 35, 868-897. http://dx.doi.org/10.1016/S0160-7383(99)00030-4

Bartlett, J. E., Kotrlik, J. W., \& Higgins, C. C. (2001). Organizational Research: Determining Appropriate Sample Size in Survey Research. Information Technology, Learning, and Performance Journal, 19(1), 43-50. Retrieved from http://citeseerx.ist.psu.edu/viewdoc/download?doi=10.1.1.486.8295\&rep=rep1\&type=pdf

Baud-Bovy, M., \& Lawson, F. (1977). Tourism and recreation development. London: Architectural Press.

Biasutti, M., \& Frezza, L. (2009). Dimensions of music improvisation. Creativity research Journal, 21(2-3), 232242.

Bigné, J. E., Sánchez, M. I., \& Sánchez, J. (2001). Tourism image, evaluation variables and after purchase behaviour: inter-relationship. Tourism Management, 22(6), 607-616.

Cavaioli, F. J. (2008). Patterns of Italian Immigration to the United States. Catholic Social Science Review, 13, 213-229. doi: 10.5840/cssr20081314

Chen, C.-F. and D. Tsai. (2007). How destination image and evaluative factors affect behavioral intentions? Tourism management. 28(4): p. 1115-1122

Chenini , \& Touaiti . (2018). Building Destination Loyalty Using Tourist Satisfaction and Destination Image: A Holistic Conceptual Framework . Journal of Tourism, Heritage \& Services Marketing, 4(2), 37-43.

Cohen, E. \& Avieli, N. (2004). Food in tourism - attraction and impediment. Annals of Tourism Research, 31(4), 755-778.

D’Antuono, L.F., \& Bignami, C. (2012). Perception of typical Ukrainian foods among an Italian population. Food Quality and Preference, 25, 1-8.

Dehlvi, S., \& Khan, O. A. (2017). Jasmine and jinns: memories and recipes of my Delhi. Noida, Uttar Pradesh, India: HarperCollins Publishers India.

Dekaphukan, P. (2019, January 16). Purani Dilli ka Khana - A Culinary Adventure through Old Delhi. Retrieved from https://www.travelscopeindia.com/blog/purani-dilli-ka-khana-a-culinary-adventure-through-olddelhi/.

Department of Homeland Security [DHS]. (2018, January 04). Table 28. Nonimmigrant Admissions (I-94 Only) By Selected Category of Admission and Region and Country Of Citizenship: Fiscal Year 2016. Retrieved from https://www.dhs.gov/immigration-statistics/yearbook/2016/table28

Duttagupta, S. (2013). Foreign travellers' recommendation of culinary tourism in India based on cuisine image and satisfaction with experiences at culinary establishments: an exploratory study (Master's thesis). University of Waterloo, Ontario, Canada.

Fischler, C. (1988). Food, self and identity. Social Science Information, 27(2), 275-292.

Gallarza, M. G., Saura, I. G., \& García, H. C. (2002). Destination image: towards a conceptual framework. Annals of Tourism Research, 29(1), 56-78. 
Gardaphé Fred L. (2004). Leaving little Italy: essaying Italian American culture. Albany: State University of New York Press.

Giddens, A. (1984). The constitution of society: outline of the theory of structuration. California : Polity Press.

Government of India. (2019). Ministry of Tourism Annual Report English (2018-2019) Ministry of Tourism. New Delhi.

Gupta, P., \& Gordon, J. P. F. (2004). Understanding India's Services Revolution. IMF Working Papers, 04(171), 1. doi: $10.5089 / 9781451858532.001$

Hair, J. F. (2011). Multivariate Data Analysis: An Overview. International Encyclopedia of Statistical Science, 904-907. doi: 10.1007/978-3-642-04898-2_395

Horng, J-S., Liu, C-H., Chou, H-Y., \& Tsai, C-Y. (2012). Understanding the impact of culinary brand equity and destination familiarity on travel intentions. Tourism Management, 33(4), 815-824.

Hunt, J.D. (1975). Image as a factor in destination development. Journal of Travel Research, 13, 1-7.

Ignatov, E., \& Smith, S. (2006). Segmenting Canadian Culinary Tourists. Current Issues in Tourism RCIT, 9(3), 235-255.

Karim, S. A. (2006). Culinary tourism as a destination attraction: an empirical examination of the destinations food image and information sources (dissertation). Oklahoma State University, Oklahoma City, OK.

Karim, S. Ab. \& Chi, A.G. (2010). Culinary tourism as destination attraction: an empirical examination of destinations' food image. Journal of Hospitality Marketing \& Management, 19, 531-555.

Kim, Yeong Gug \& Eves, Anita \& Scarles, Caroline. (2009). Building a Model of Local Food Consumption on Trips and Holidays: A Grounded Theory Approach. International Journal of Hospitality Management. 28. 423-431. 10.1016/j.ijhm.2008.11.005.

Lee, T-H., \& Crompton, J. (1992). Measuring novelty seeking in tourism. Annals of Tourism Research, 19(4), 732-751.

Lertputtarak, S. (2012). The Relationship between Destination Image, Food Image, and Revisiting Pattaya, Thailand. International Journal of Business and Management, 7(5). doi: 10.5539/ijbm.v7n5p111

Lin, Y. C. (2006). Food images in destination marketing [Unpublished doctoral thesis]. Purdue University, Lafayette, IN.

Lin, Y-C., Pearson, T.E., \& Cai, L.A. (2011). Food as a form of destination identity: a tourism destination brand perspective. Tourism and Hospitality Research, 11(1), 30-48.

Lupton, D. (1996). Food, the body and self. London: Sage.

Mills, J. (2005). Addres.sing the concems of conservatoire students about school music teaching. British Journal of Music Education, 22(1), 63-75.

Nadeau, J., Heslop, L., O'Reilly, N., \& Luk, P. (2008). Destination in a country image context. Annals of Tourism Research, 35(1), 84-106. doi: 10.1016/j.annals.2007.06.012

Pant, P. (2013). India cookbook. London: Phaidon.

Quan, S. \& Wang, N. (2004). Towards a structural model of the tourist experience: an illustration from food experiences in tourism. Tourism Management, 25(3), 297-305.

Rahman, N. (2017, May 17). Category: Cultural Traditions and Rituals. Retrieved from https://eportfolios.macaulay.cuny.edu/lobel17/category/cultural-traditions-and-rituals/. 
Scott, R., Schewe, C. \& Frederick, D. (1978). A multi-brand/multi-attribute model of tourist state choice. Journal of Travel Research, 17(3), 23-29.

Shenoy, S. (2005). Food tourism and the culinary tourist. [Doctoral dissertation], Retrieved from Libraries Australia, (46025053)

Smith, S., 2007. Analysis of tourists attending a culinary event: Motivations, satisfaction, and behavioural outcomes. [Doctoral dissertation, University of Tennessee, Knoxville].

Snedecor, G. W., \& Cochran, W. G. (1989). Statistical methods. Ames, IA: Iowa State University Press.

Soofi, M. A. (2010). The Delhi walla hangouts. Noida: Collins.

Tapachai, N., \& Waryszak, R., (2000). An examination of the role of beneficial image in tourist destination selection. Journal of Travel Research, 39, 37-44.

Tardi, A. (2007, October 24). Spacious Food Bazaar in Turin Plans Manhattan Branch. Retrieved from https://www.nytimes.com/2007/10/24/dining/24eata.html.

The Hindu. (2016, October 13). Presenting India in a microcosm. Retrieved from https://www.thehindu.com/news/cities/Delhi/Presenting-India-in-a-microcosm/article16069611.ece.

Tikkanen, I. (2007). Maslow's hierarchy and food tourism in Finland: five cases. British Food Journal, 109(9), 721734.

Vishal, A. (2015, October 11). Delhi: The diversity of the Capital's food is a reflection of the many kinds of people who call it their home. Retrieved from https://economictimes.indiatimes.com.

Wang, C-Y., \& Hsu, M. K. (2010). The relationships of destination image, satisfaction, and behavioral intentions: an integrated model. Journal of Travel and Tourism Marketing, 27(8), 829-843. 